\title{
Susceptibility of Grapholita molesta to insecticides in Brazil
}

\author{
Oscar Arnaldo Batista Neto e Silva ${ }^{1}$ Marcos Botton ${ }^{2}$ \\ Daniel Bernardi ${ }^{*}$ Cristiano João Arioli ${ }^{4}$ Celso Omoto ${ }^{5}$
}

\author{
${ }^{1}$ Dow AgroSciences LTDA, Ribeirão Preto, SP, Brasil. \\ ${ }^{2}$ Empresa Brasileira de Pesquisa Agropecuária (Embrapa Uva e Vinho), Bento Gonçalves, RS, Brasil. \\ ${ }^{3}$ Universidade Federal de Pelotas (UFPEL), 96010-970, Pelotas, RS, Brasil. E-mail: dbernardi2004@yahoo.com.br. *Corresponding author. \\ ${ }^{4}$ Empresa de Pesquisa Agropecuária e Extensão Rural de Santa Catarina (EPAGRI), Videira, SC, Brasil. \\ ${ }^{5}$ Escola Superior de Agricultura Luiz de Queiroz (ESALQ/USP), Piracicaba, SP, Brasil.
}

\begin{abstract}
The use of insecticides has been the main tool for Grapholita molesta (Busck) control in Brazil, which is considered one of the most important pests in apple and peach orchards. In order to implement an Insect Resistance Management (IRM) program, studies were conducted to characterize the baseline susceptibility of G. molesta to major insecticides for its control. Then, we conducted an insecticide susceptibility monitoring in thirteen field-collected populations of the pest. Neonates (0-24h old) were exposed to insecticides applied on surface of artificial diet. A high susceptibility was verified when neonates of the Laboratory population of G. molesta were exposed to insecticides with $\mathrm{LC}_{50}$ values ( $\mu \mathrm{g}$ a.i./( $\mathrm{cm}^{2}$ ) of 0.1 (spinetoram), 1.0 (metaflumizone), 1.2 (chlorantraniliprole), 4.8 (novaluron), 5.1 (tebufenozide), 11.3 (phosmet) and 222.5 (pyriproxyfen). Based on the $L C_{99}\left(\mu \mathrm{g}\right.$ a.i./ $\mathrm{cm}^{2}$ ), the diagnostic concentrations of 0.6 (spinetoram), 5.5 (metaflumizone), 5.6 (chlorantraniliprole), 19.6 (tebufenozide), 37.4 (phosmet), 37.8 (novaluron) and 2011 pyriproxyfen) caused high mortality (>95\%) of neonates from field populations. These diagnostic concentrations will be used in resistance monitoring programs of G. molesta in Brazil. Key words: chemical control, insect resistance management; oriental fruit moth.
\end{abstract}

\section{Suscetibilidade de Grapholita molesta a inseticidas no Brasil}

RESUMO: O uso de inseticidas tem sido a principal ferramenta para o controle da Grapholita molesta (Busck) no Brasil, considerada uma das mais importantes pragas em pomares de macieira e pessegueiro. Para implementar um programa de Manejo de Resistência a Insetos (MRI), estudos foram conduzidos para estabelecer uma linha básica de suscetibilidade de G. molesta a inseticidas utilizados para o seu controle. Posteriormente, foi realizado o monitoramento da suscetibilidade a inseticidas em treze populações da praga provenientes do campo. Lagartas (0-24 horas de idade) foram expostas a inseticidas aplicados na superficie da dieta artificial. Verificou-se alta suscetibilidade de lagartas neonatas de G. molesta (população de laboratório) quando foram expostas aos inseticidas, com valores de $C L_{50}\left(\boldsymbol{\mu g}\right.$ i.a./ $\left.\mathrm{cm}^{2}\right)$ de 0,1 (espinetoram), 1,0 (metoxifenozida), 1,2 (clorantraniliprole), 4,8 (novaluron), 5,1 (tebufenozida), 11,3 (fosmete) e 222,5 (piriproxifem). Com base na CL ${ }_{99}$ ( $\boldsymbol{\text { g }}$ i.a./ $\mathrm{cm}^{2}$ ), as concentrações diagnósticas de 0,6 (espinetoram), 5,5 (metaflumizona), 5,6 (clorantraniliprole), 19,6 (tebufenozida), 37,4 (fosmete), 37,8 (novaluron) e 2.011 (piriproxifem) ocasionaram alta mortalidade (>95\%) de neonatas provenientes de populações de campo. Essas concentrações diagnósticas poderão ser utilizadas em programas de monitoramento da resistência de G. molesta no Brasil.

Palavras-chave: controle químico, manejo de resistência de insetos, mariposa-oriental.

\section{INTRODUCTION}

The oriental fruit moth Grapholita molesta (Busck, 1916) (Lepidoptera: Tortricidae) is native from China and is now distributed throughout temperate regions of the world, being considered the most important pest in apple and peach orchards in Brazil (BOTTON et al., 2011). The control of $G$. molesta in Brazil has been carried out mainly using organophosphorate insecticides (chlorpyrifos and phosmet) and insect growth regulators (lufenuron and novaluron) (ARIOLI et al., 2010). However, new insecticides (chlorantraniliprole and spinetoram) have been introduced in the Brazilian market for G. molesta management (CHAVES et al., 2014).

Resistance of $G$. molesta to organophosphate insecticides has been identified in Canada, United States (USMANI \& SHEARER, 2001) and Brazil (SIEGWART et al., 2011). Resistance evolution is a serious threat for the chemical control sustainability of the oriental fruit moth when we consider the high insecticide selection pressure in Brazil (6-8 treatments per season) (BOTTON et al., 2011), its polyphagy (preference for apple and peach) and its high reproductive ability 
(6 generations per year) (ARIOLI et al., 2010). These aspects are an alert for the risk of resistance evolution of $G$. molesta to insecticides in Brazilian orchards production systems.

In this scenario, the resistance monitoring must be emphasized in Insect Resistance Management (IRM) programs for the preservation of the durability of insecticides and to prevent control failure in the pest management program (ROUSH \& MILLER, 1986). Within this context, it is essential to understand the natural response of distinct geographic populations of the target pest, through the characterization of the baseline susceptibility and estimate the diagnostic concentration of each insecticide for the development of an IRM program (ROUSH \& MILLER, 1986).

Therefore, objectives of the current study were to characterize the baseline susceptibility to insecticides in G. molesta and to validate diagnostic concentration for IRM programs in geographically distinct populations of $G$. molesta collected in the main producing regions of apple and peach in Brazil.

\section{MATERIAL AND METHODS}

\section{Insect populations}

For insecticides susceptibility characterization, we used a reference susceptible population (population of Laboratory) of G. molesta that has been maintained in the laboratory, free from selection pressure by insecticides, for 10 years, reared in the an artificial diet (ARIOLI et al., 2010). To validate the candidate diagnostic insecticide concentrations, we collected larvae from 13 G. molesta populations from orchards located in different municipalities of the state of Rio Grande do Sul, Santa Catarina and São Paulo, Brazil (Table 1).

\section{Chemicals}

The testedinsecticideswere chlorantraniliprole (Altacor $350 \mathrm{WG}^{\mathrm{TM}}$ - 4.9g a.i. $100 \mathrm{~L}^{-1}$, DuPont do Brasil S.A. - Barueri, SP), metaflumizone (BAS 320I - 14.0g a.i. 100L $\mathrm{L}^{-1}$, Basf S.A., São Paulo, SP), novaluron (Rimon $100 \mathrm{EC}^{\mathrm{TM}}$ - 4.0g a.i. $100 \mathrm{~L}^{-1}$, Adama Brasil Londrina, PR), phosmet (Imidan $500 \mathrm{WP}^{\mathrm{TM}}$ - Cross Link Consultoria e Comércio, Barueri, SP), pyriproxyfen (Tiger ${ }^{\mathrm{TM}}$, 10.0g a.i. $100 \mathrm{~L}^{-1}$, Sumitomo chemical do Brasil Repres. Ltda, São Paulo, SP), spinetoram (Delegate $250 \mathrm{WG}^{\mathrm{TM}}-7.5 \mathrm{~g}$ a.i. 100L ${ }^{-1}$, Dow AgroSciences Industrial Ltda, São Paulo, SP), spinosad (Tracer $480 \mathrm{SC}^{\mathrm{TM}}$ - 7.5g a.i. $100 \mathrm{~L}^{-1}$, Dow Agro Sciences Industrial Ltda - São Paulo, SP) and tebufenozide (Mimic 240 SC $^{\mathrm{TM}}$ - 21.6g a.i. 100L $\mathrm{L}^{-1}$, Dow Agro Sciences Industrial Ltda, São Paulo, SP).

\section{Baseline susceptibility in diet overlay bioassays}

For the bioassays, we used the artificial diet proposed by ARIOLI et al. (2010), commonly used for rearing $G$. molesta. After preparation, the artificial diet was kept in bath regulated at $50^{\circ} \mathrm{C}$ and, posteriorly, $1.25 \mathrm{~mL}$ were transferred to 24 -well acrylic plates (COSTARTM). Afterwards, the insecticides were diluted in distilled water to prepare the different concentrations to be tested. The surfactant Triton $\mathrm{X}-100$ was added at $0.1 \%$ in order to obtain a uniform spread of the solution over the diet surface. The control treatment was composed of distilled water + surfactant. For each insecticide, we tested seven concentrations logarithmically spaced that caused $10-99 \%$ mortality in a preliminary test, which were applied on the diet surface with a replication pipette $(30 \mu \mathrm{l}$ per well). After a drying period (90min), one G. molesta neonate larvae (0-24h old) was added to each well using a fine brush. The acrylic plates were covered with a lid and were kept in a climatic chamber (temperature $25 \pm 2^{\circ} \mathrm{C}$,

Table 1 - Identification of G. molesta populations, host, source and collection date to susceptibility monitoring.

\begin{tabular}{|c|c|c|c|c|c|}
\hline Population Code & Host & City, State & Longitude & Latitude & Date \\
\hline \multicolumn{6}{|c|}{ 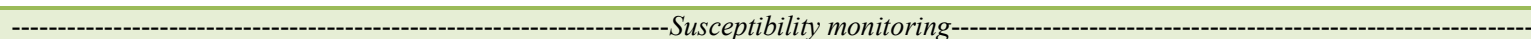 } \\
\hline Laboratory & - & Pelotas, RS & $31^{\circ} 48^{\prime} 8^{\prime \prime} \mathrm{S}$ & $52^{\circ} 24^{\prime} 55^{\prime \prime} \mathrm{W}$ & - \\
\hline $\mathrm{P} / \mathrm{SP} 1$ & Peach & Paranapanema, SP & $48^{\circ} 39^{\prime} 17^{\prime \prime} \mathrm{S}$ & $23^{\circ} 20^{\prime} 26^{\prime \prime} \mathrm{W}$ & October 2010 \\
\hline $\mathrm{M} / \mathrm{SC} 1$ & Apple & São Joaquim, SC & $49^{\circ} 55^{\prime} 55^{\prime \prime} \mathrm{S}$ & $28^{\circ} 17^{\prime} 38^{\prime \prime} \mathrm{W}$ & October 2010 \\
\hline $\mathrm{M} / \mathrm{RS} 3$ & Apple & Vacaria, RS & $50^{\circ} 58.945^{\prime} \mathrm{S}$ & $28^{\circ} 33.003^{\prime} \mathrm{W}$ & October 2010 \\
\hline $\mathrm{P} / \mathrm{SP} 2$ & Peach & Paranapanema, SP & $48^{\circ} 39^{\prime} 17^{\prime \prime} \mathrm{S}$ & $23^{\circ} 20^{\prime} 26^{\prime \prime} \mathrm{W}$ & November 2011 \\
\hline $\mathrm{M} / \mathrm{SC} 2$ & Apple & São Joaquim, SC & $50^{\circ} 06.591^{\prime} \mathrm{S}$ & $27^{\circ} 55011^{\prime} \mathrm{W}$ & November 2011 \\
\hline $\mathrm{M} / \mathrm{RS} 1$ & Apple & Caxias do Sul, RS & $50^{\circ} 55^{\prime} 17^{\prime \prime} \mathrm{S}$ & $27^{\circ} 01^{\prime} 34^{\prime \prime} \mathrm{W}$ & November 2011 \\
\hline $\mathrm{M} / \mathrm{RS} 2$ & Apple & Antônio Prado, RS & $51^{\circ} 16^{\prime} 58^{\prime \prime} \mathrm{S}$ & $28^{\circ} 51^{\prime} 28^{\prime} \mathrm{W}$ & November 2011 \\
\hline P/RS1 & Peach & Pinto Bandeira, RS & $51^{\circ} 24.9^{\prime} 65^{\prime} \mathrm{S}$ & $29^{\circ} 07.606^{\prime} \mathrm{W}$ & December 2012 \\
\hline $\mathrm{P} / \mathrm{RS} 2$ & Peach & Pelotas, RS & $52^{\circ} 32.8^{\prime} 84^{\prime} \mathrm{S}$ & $31^{\circ} 25.750^{\circ} \mathrm{W}$ & December 2012 \\
\hline $\mathrm{P} / \mathrm{RS} 3$ & Peach & Pelotas, RS & $52^{\circ} 32.5^{\prime} 45^{\prime} \mathrm{S}$ & $31^{\circ} 25.953^{\prime} \mathrm{W}$ & December 2012 \\
\hline M/RS4 & Apple & Pinto Bandeira, RS & $51^{\circ} 24.4^{\prime} 95^{\prime} \mathrm{S}$ & $29^{\circ} 08.203^{\prime} \mathrm{W}$ & December 2012 \\
\hline $\mathrm{M} / \mathrm{SP} 1$ & Apple & Paranapanema, SP & $48^{\circ} 43^{\prime} 22^{\prime \prime} \mathrm{S}$ & $23^{\circ} 23^{\prime} 20^{\prime \prime} \mathrm{W}$ & December 2012 \\
\hline M/RS5 & Apple & Bento Gonçalves, RS & $51^{\circ} 31^{\prime} 08^{\prime \prime} \mathrm{S}$ & $29^{\circ} 10^{\prime} 01^{\prime \prime} \mathrm{W}$ & December 2012 \\
\hline
\end{tabular}

Ciência Rural, v.48, n.1, 2018. 
relative humidity $60 \pm 10 \%$ and photoperiod $16: 8$ [L:D] h). The assessment of the mortality for the insecticides metaflumizone and phosmet was accomplished 1 day after inoculation (DAI), 3 DAI for the chlorantraniliprole, novaluron, spinetoram and tebufenozide and 5 DAI for pyriproxyfen. Individuals were considered dead if they showed no reaction to a brush touch. The experimental design was completely randomized with five replications (one 24-well acrylic plate for repetition, 48 larvae per acrylic plate) for each concentration, totaling 192 larvae per concentration.

\section{Validation of candidate diagnostic concentrations}

The bioassay procedure for the validation of the diagnostic insecticide concentrations for resistancemonitoring programs was identical to that described above. The bioassays used the same susceptible population (laboratory reference population) and 13 populations of G. molesta (Table 1). Field populations represent regions with the greatest crop production of apple and peach in Brazil and the orchards were selected based on records of control failure reported by technicians and growers. Larvae were collected from the field during the 2010 to 2012 apple-growing season and reared in the laboratory on an artificial diet according to the procedures described in ARIOLI et al. (2010). For each collected population, neonate larvae (0-24 h old, generation F2) were exposed to a diagnostic concentration (based on the values of $\mathrm{LC}_{99}$ ) of insecticide defined in the joint analysis of the baseline susceptibility data. For each diagnostic concentration of each insecticide we tested 624 neonates per population (13 replicate of 48 neonates per replicate). Mortality evaluation was performed as described above (baseline susceptibility). The mortality was corrected using the formula ABBOTT's (1925).

\section{Statistical analysis}

The $\mathrm{LC}_{50}$ and $\mathrm{LC}_{90}$ (Lethal Concentration) estimates, the respective confidence intervals (CI 95\%) and the angular coefficient data on insect mortality were obtained from Probit analyses (PROC PROBIT, SAS INSTITUTE, 2011). A likelihood ratio test was conducted to test the hypothesis that the LCp values were equal. If the hypothesis was rejected, pairwise comparisons were performed and the significance was declared if confidence intervals did not overlap (ROUSH \& MILLER, 1986). The significance of differences among slopes was determined by likelihood ratio test for parallelism and equality (ROUSH \& MILLER, 1986).To estimate the $\mathrm{LC}_{99}$, the larval mortality data for each insecticide were analyzed jointly with a binomial model using the log-log complement connection function (gompit; PROC PROBIT) (SAS INSTITUTE, 2011). Through this analysis, $\mathrm{LC}_{99}$ values and the respective CIs were estimated to determine the diagnostic concentrations for the resistance monitoring of $G$. molesta. To validate the candidate diagnostic concentrations, the $G$. molesta mortality percentage (x) in each diagnostic concentration and population were transformed in arcsen $\sqrt{x / 100}$ and the means submitted to analysis of variance (ANOVA) and, when significant $(P \leq 0.05)$, the means were compared using Tukey's test $(P \leq 0.05)$ (SAS INSTITUTE, 2011).

\section{RESULTS}

Baseline susceptibility in diet overlay bioassays

We observed high susceptibility of $G$. molesta to the tested insecticides (Table 2), especially to spinetoram $\left(\mathrm{LC}_{50}=0.1 \mu \mathrm{g}\right.$ a.i. $\left./ \mathrm{cm}^{2}\right)$, in relation to

Table 2 - Lethal concentrations (LC: $\mu \mathrm{g}$ a.i. $/ \mathrm{cm}^{2}$ ) of insecticides to G. molesta neonate larvae (Laboratory population) from an artificial diet overlay bioassay.

\begin{tabular}{|c|c|c|c|c|c|}
\hline Insecticide & $n$ & Slope $( \pm \mathrm{SE})$ & $\mathrm{LC}_{50}(95 \% \mathrm{FL})^{a}$ & $\mathrm{LC}_{90}(95 \% \mathrm{FL})^{a}$ & $\chi^{2 b}$ (d.f.) $)^{c}$ \\
\hline Spinetoram & 672 & $2.5( \pm 0.3) b$ & $0.1(0.5-0.10) \mathrm{a}$ & $0.3(0.2-0.4) \mathrm{a}$ & $4.8(3)$ \\
\hline Metaflumizone & 829 & $2.5( \pm 0.2) b$ & $1.0(0.5-1.3) b$ & $2.9(2.6-3.4) b$ & $16.2(4)$ \\
\hline Chlorantraniliprole & 1.432 & $2.9( \pm 0.2) b c$ & $1.2(1.0-1.3) b$ & $3.2(2.8-3.5) b$ & $7.2(7)$ \\
\hline Novaluron & 760 & $2.2( \pm 0.2) \mathrm{ab}$ & $4.8(3.9-5.5) \mathrm{c}$ & $17.7(14.5-23.6) \mathrm{d}$ & $7.0(4)$ \\
\hline Tebufenozide & 893 & $3.3( \pm 0.3) \mathrm{c}$ & $5.1(4.6-5.7) \mathrm{c}$ & $12.2(10.9-14.0) \mathrm{c}$ & $4.8(4)$ \\
\hline Phosmet & 1250 & $3.0( \pm 0.4) \mathrm{c}$ & $11.3(10.2-12.4) \mathrm{d}$ & $24.6(22.2-27.7) \mathrm{d}$ & $1.9(5)$ \\
\hline Pyriproxyfen & 978 & $1.7( \pm 0.2) \mathrm{a}$ & $222.5(160.3-282.9) \mathrm{e}$ & $964.6(825.0-1199.0) \mathrm{e}$ & $13.8(4)$ \\
\hline
\end{tabular}

${ }^{a} \mathrm{LC}_{50}$ and $\mathrm{LC}_{90}$ : Insecticide concentrations ( $\mu \mathrm{g}$ of active ingredient (a.i.) $/ \mathrm{cm}^{2}$ ) required to kill 50 or $90 \%$ of the larvae, respectively. Significance of differences among slopes determined by likelihood ratio test of equality followed by pairwise comparisons using nonoverlapping fiducial limits, ${ }^{b} \mathrm{Chi}$-square, ${ }^{c}$ Degrees of freedom. 
metaflumizone $\left(\mathrm{LC}_{50}=1.0 \mu \mathrm{g}\right.$ a.i. $\left./ \mathrm{cm}^{2}\right)$, chlorantraniliprole $\left(\mathrm{LC}_{50}=1.2 \mu \mathrm{g}\right.$ a.i. $\left./ \mathrm{cm}^{2}\right)$, novaluron $\left(\mathrm{LC}_{50}=4.8 \mu \mathrm{g}\right.$ a.i. $/$ $\left.\mathrm{cm}^{2}\right)$, tebufenozide $\left(\mathrm{LC}_{50}=5.1 \mu \mathrm{g}\right.$ a.i. $\left./ \mathrm{cm}^{2}\right)$, phosmet $\left(\mathrm{CL}_{50}=11.3 \mu \mathrm{g}\right.$ a.i. $\left./ \mathrm{cm}^{2}\right)$ and pyriproxyfen $\left(\mathrm{LC}_{50}=222.5 \mu \mathrm{g}\right.$ a.i. $/ \mathrm{cm}^{2}$ ) (Table 2). Similarly, there were significant differences in susceptibility of $G$. molesta based on the values of $\mathrm{LC}_{90}$ (Table 2). From the joint analysis of mortality data for each insecticide, we estimated candidate diagnostic concentrations for $G$. molesta resistance monitoring in Brazil were the $\mathrm{LC}_{99}$ of $0.6 \mu \mathrm{g}$ a.i. $/ \mathrm{cm}^{2}$

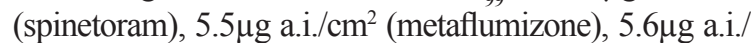
$\mathrm{cm}^{2}$ (chlorantraniliprole), $19.6 \mu \mathrm{g}$ a.i./ $\mathrm{cm}^{2}$ (tebufenozide), $37.4 \mu \mathrm{g}$ a.i. $/ \mathrm{cm}^{2}$ (phosmet), $37.8 \mu \mathrm{g}$ a.i. $/ \mathrm{cm}^{2}$ (novaluron), and $2011 \mu \mathrm{g}$ a.i. $/ \mathrm{cm}^{2}$ (pyriproxyfen).

\section{Diagnostic concentrations for resistance monitoring}

There was low variation in the susceptibility of the G. molesta field populations to the diagnostic insecticide concentrations (Table 3). The M/SP1 of $G$. molesta population from a peach orchard in the municipality of Paranapanema, SP, to phomet, was significantly less susceptible to insecticide (97.5 of mortality) when compared $\left(\mathrm{F}_{7,96}=2.80 ; P<0.0001\right)$ to the other populations collected during the season of 2010/11 (Table 3). In the same way, a less susceptibility $\left(\mathrm{F}_{8,109}=8.57 ; P<0.0001\right)$ was also observed from $\mathrm{M} /$ SC1 (95.5 of mortality) of the G. molesta population from an apple orchard in the municipality of São Joaquim/RS, to tebufenozide (Table 3). However, in the 2011/12 season, all populations showed similar susceptibility $\left(\mathrm{F}_{7,96}=4.61 ; P=0.2215\right)$ to that observed for Laboratory population (Table 3 ).

\section{DISCUSSION}

The bioassay technique used (surface treatment of artificial diet), the Probit and log-log complementary analysis, showed consistency to describe the biological responses of $G$. molesta larvae to the insecticides evaluated. Furthermore, it is a realistic technique with the pest behavior in the field when $G$. molesta larvae ingest the insecticide that is presented on the surface of the pointers or ripe fruit before penetration in the host (CHAVES et al., 2014). G. molesta neonates from the reference population (Laboratory) were susceptible to all tested insecticides on the surface of the artificial diet. Due to these methodological differences, some $\mathrm{LC}_{50}$ values reported in this study differ from those obtained by other authors (SIEGWART et al., 2011). However, these authors used other techniques bioassays and a longer exposition time of larvae to insecticides. Therefore, the sum of these factors reflects the difference of values reported in this study compared to those reported in the literature.

Table 3 - Mortality (mean \pm SE) of $G$. molesta neonate larvae from apple and peach orchards when compared to the susceptible laboratory population exposed to one candidate diagnostic concentration of insecticides overlaid on an artificial diet.

\begin{tabular}{|c|c|c|c|c|c|c|c|}
\hline \multirow{2}{*}{ Population code } & \multicolumn{7}{|c|}{ 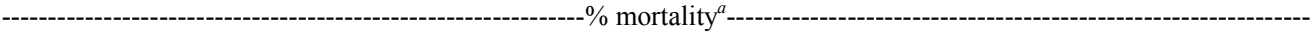 } \\
\hline & Spi. & Meta. & Chlora. & Nova. & Tebu. & Phos. & Pyri. \\
\hline \multicolumn{8}{|c|}{ 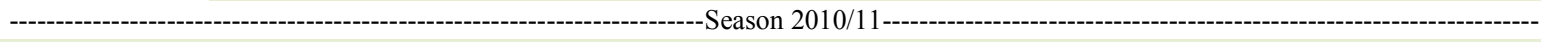 } \\
\hline Laboratory & $99.8 \pm 0.5^{\text {ns }}$ & $98.5 \pm 0.6^{\mathrm{ns}}$ & $100.0 \pm 0.0^{\mathrm{ns}}$ & $99.3 \pm 0.0^{\mathrm{ns}}$ & $99.0 \pm 0.5 \mathrm{c}$ & $99.8 \pm 0.2 b$ & $100.0 \pm 0.0^{\mathrm{ns}}$ \\
\hline $\mathrm{P} / \mathrm{SP} 1$ & $97.0 \pm 0.5$ & $99.7 \pm 0.5$ & $100.0 \pm 0.0$ & $99.5 \pm 0.2$ & $96.6 \pm 0.7 b$ & $97.5 \pm 0.7 \mathrm{a}$ & $100.0 \pm 0.0$ \\
\hline $\mathrm{M} / \mathrm{SC} 1$ & $96.8 \pm 0.9$ & $100.0 \pm 0.0$ & $100.0 \pm 0.0$ & $99.1 \pm 0.4$ & $95.5 \pm 0.7 \mathrm{a}$ & $98.6 \pm 0.4 b$ & $100.0 \pm 0.0$ \\
\hline $\mathrm{M} / \mathrm{SC} 2$ & $97.7 \pm 0.3$ & $98.2 \pm 0.8$ & $100.0 \pm 0.0$ & $99.8 \pm 0.1$ & $99.9 \pm 0.4 \mathrm{c}$ & $98.8 \pm 0.2 \mathrm{~b}$ & $100.0 \pm 0.0$ \\
\hline $\mathrm{M} / \mathrm{RS} 1$ & $99.4 \pm 0.3$ & $98.4 \pm 0.6$ & $100.0 \pm 0.0$ & $98.8 \pm 0.3$ & $99.2 \pm 0.4 \mathrm{c}$ & $99.8 \pm 0.1 \mathrm{~b}$ & $100.0 \pm 0.0$ \\
\hline M/RS2 & $98.1 \pm 0.8$ & $98.2 \pm 0.7$ & $100.0 \pm 0.0$ & $100.0 \pm 0.0$ & $99.8 \pm 0.2 \mathrm{c}$ & $99.0 \pm 0.4 \mathrm{~b}$ & $100.0 \pm 0.0$ \\
\hline $\mathrm{M} / \mathrm{RS} 3$ & $98.2 \pm 0.7$ & $98.0 \pm 0.8$ & $100.0 \pm 0.0$ & $99.0 \pm 0.4$ & $99.4 \pm 0.4 c$ & $99.6 \pm 0.2 b$ & $100.0 \pm 0.0$ \\
\hline \multicolumn{8}{|c|}{ 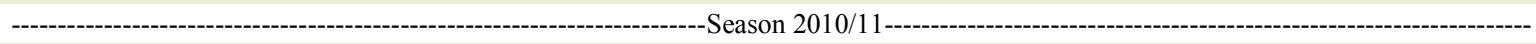 } \\
\hline Laboratory & $99.7 \pm 0.3^{\text {ns }}$ & $99.4 \pm 0.4^{\mathrm{ns}}$ & $99.5 \pm 0.3^{\mathrm{ns}}$ & $99.1 \pm 0.4^{\mathrm{ns}}$ & $99.0 \pm 0.5^{\mathrm{ns}}$ & $99.1 \pm 0.4^{\mathrm{ns}}$ & $100.0 \pm 0.0^{\mathrm{ns}}$ \\
\hline $\mathrm{P} / \mathrm{RS} 1$ & $98.9 \pm 0.6$ & $99.0 \pm 0.4$ & $100.0 \pm 0.0$ & $99.1 \pm 0.8$ & $99.6 \pm 0.8$ & $97.7 \pm 0.5$ & $100.0 \pm 0.0$ \\
\hline $\mathrm{P} / \mathrm{RS} 2$ & $99.0 \pm 0.4$ & $99.0 \pm 0.4$ & $99.2 \pm 0.1$ & $99.7 \pm 0.6$ & $98.8 \pm 0.3$ & $99.8 \pm 0.5$ & $100.0 \pm 0.0$ \\
\hline $\mathrm{P} / \mathrm{RS} 3$ & $99.2 \pm 0.6$ & $97.7 \pm 0.8$ & $99.7 \pm 0.2$ & $99.1 \pm 0.6$ & $98.8 \pm 0.4$ & $99.2 \pm 0.3$ & $100.0 \pm 0.0$ \\
\hline P/SP2 & $100.0 \pm 0.0$ & $99.6 \pm 0.2$ & $99.6 \pm 0.2$ & $98.8 \pm 0.7$ & $98.6 \pm 0.6$ & $97.6 \pm 0.8$ & $100.0 \pm 0.0$ \\
\hline $\mathrm{M} / \mathrm{RS} 4$ & $99.7 \pm 0.2$ & $98.6 \pm 0.2$ & $98.8 \pm 0.2$ & $99.5 \pm 0.5$ & $99.4 \pm 0.3$ & $97.4 \pm 0.2$ & $100.0 \pm 0.0$ \\
\hline M/SP1 & $100.0 \pm 0.0$ & $98.5 \pm 0.6$ & $99.8 \pm 0.2$ & $99.9 \pm 0.1$ & $99.8 \pm 0.2$ & $98.5 \pm 0.5$ & $100.0 \pm 0.0$ \\
\hline M/RS5 & $99.6 \pm 0.2$ & $99.2 \pm 0.3$ & $99.6 \pm 0.2$ & $98.8 \pm 0.7$ & $99.8 \pm 0.6$ & $99.0 \pm 0.6$ & $100.0 \pm 0.0$ \\
\hline
\end{tabular}

${ }^{a}$ Values represent means \pm SE. Means followed by the same letter in each season and each candidate diagnostic concentration do not differ statistically (Tukey test, $P<0.05$ ). ${ }^{\text {ns: }}$ not significant in column, Spi: Spinetoram, Meta: Metaflumizone, Chlora: Chlorantraniliprole, Nova: Novaluron. Tebu: Tebufenozide, Phos: Phosmet, Pyri: Pyriproxifen, 
Regarding the susceptibility monitoring, a high susceptibility was observed on the $G$. molesta populations collected in different sites to the insecticides (chlorantraniliprole, metaflumizone, pyriproxyfen and spinetoram) (CHAVES et al., 2014). The differences observed in larval survival to the phosmet and tebufenozide insecticides may be due to the presence of natural susceptibility variability in geographically distinct populations. However, we cannot discard the possibility of evolution of resistance to these insecticides, as observed by SIEGWART et al. (2011) in Brazil, for the insecticides organophosphate, pyrethroid and carbamate in Canada (KANGA et al., 2003) and to azinphosmethyl in New Jersey, EUA (USMANI \& SHEARER, 2001).

The estimate of baselines and monitoring of susceptibility of $G$. molesta to insecticides provide information to the establishment of proactive IRM program as verified to Bonagota salubricola (Meyrick) (Lepidoptera: Tortricidae) in apple orchards in Brazil (BERNARDI et al., 2016). The initiative also allowed monitoring changes in pest susceptibility over time and define IRM strategies,; for example, in the rotation of insecticides with different modes of action (ROUSH \& MILLER, 1986; SPARKS \& NAUEN, 2015). This management strategy allowed the reduction of the frequency of resistant individuals of G. molesta to organophosphate insecticide from 55 to $14 \%$ and to pyrethroids from 30 to $10 \%$ in peach orchards in Canada (KANGA et al., 2003).

In Brazil, this strategy can also help delay or avoid the evolution of resistance in populations of $G$. molesta due the populations present low genetic variability (SILVA-BRANDÃO et al., 2015). However, the low gene flow between G. molesta populations (SILVA-BRANDÃO et al., 2015) may contribute for the occurrence of evolution of resistance more quickly in local populations, since there is no introduction of susceptibility alleles (susceptible individuals) in the population by increasing the frequency of resistant individuals on site (KANGA et al., 2003). Therefore, the use of insecticides in apple and peach orchards should be done with caution, once that the molecules of insecticides available or registered for the $G$. molesta management are practically the same for the two crops.

To subsidize an IRM program, the monitoring of the susceptibility of $G$. molesta to insecticide is of critical importance to maintain the efficiency and control in the field. For susceptibility monitoring, the diagnostic concentrations of each insecticide caused a high mortality of the neonates for these pest insects. These results are very important for IRM programs of $G$. molesta, once with the diagnostic concentrations (obtained from the $\mathrm{LC}_{99}$ ) reported in the present study for each insecticide are very similar to the concentrations used by the growers to control G. molesta in the field.

Therefore, the compilation of this susceptibility database for populations of G. molesta, and the validation of the diagnostic concentration to insecticide will be useful in the follow up of possible changes in the susceptibility of this pest. Future efforts should be concentrated on representative samples of populations of these target pests and to give continuity to the studies to evaluate the susceptibility of G. molesta insecticide for detecting in advance the possibility of the presence of resistant individuals on apple and peach orchards to prevent or delay the evolution of resistance.

\section{CONCLUSION}

The G. molesta populations showed high susceptibility to insecticides spinetoram, metaflumizone, chlorantraniliprole, novaluron, tebufenozide, phosmet and pyriproxyfen.

Diagnostic concentrations $(\mu \mathrm{g} \quad$ a.i./ $\left.\mathrm{cm}^{2}\right) \quad 0.6$ (spinetoram), 5.5 (metaflumizone), 5.6 (chlorantraniliprole), 19.6 (tebufenozide), 37.4 (phosmet), 37.8 (novaluron) and 2,011 (pyriproxyfen) may be used in IRM programs of G. molesta in Brazil.

\section{ACKNOWLEDGMENTS}

The authors are grateful to the Coordenação de Aperfeiçoamento de Pessoal de Nível Superior (CAPES) for granting a scholarship to the first author and the Comitê Brasileiro de Ação a Resistência a Inseticidas (IRAC-BR) for providing the insecticide samples.

\section{REFERENCES}

ABBOTT, W.S. A method of computing the effectiveness of an inseticide. Journal of Economic Entomology, v.18, n.1, p. 265267, 1925. Available from: <https://doi.org/10.1093/jee/18.2.265a >. Accessed: Aug. 17, 2017. doi: 10.1093/jee/18.2.265a.

ARIOLI, C.J..et al. Biologia da mariposa-oriental em dieta artificial à base de milho. Scientia Agraria, v.11, n.6, p.481-486. 2010.

BERNARDI, D. et al. Susceptibility of Bonagota salubricola (Lepidoptera: Tortricidae) to Insecticides in Brazilian Apple Orchards: Implications for Resistance Management. Journal Economic of Entomology, v.22, n.4, p.1-6, 2016. Available from: <http://doi:10.1093/ jee/tow143>. Accessed: Sep. 15, 2017. doi: 10.1093/jee/tow143.

BOTTON, M. et al. Bioecologia, monitoramento e controle da mariposa-oriental na cultura do pessegueiro no Rio Grande do Sul. Bento Gonçalves: Embrapa Uva e Vinho, 2011, 11p. (Circular Técnica, 86). 
CHAVES, C.C. et al. Efeito de inseticidas em diferentes fases de desenvolvimento de Grapholita molesta (Busck, 1916) (Lepidoptera: Tortricidae) e estruturas vegetais da macieira e do pessegueiro. Revista Brasileira de Fruticultura, v. 36, n.4, p. 842-852, 2014. Available from: <http://dx.doi.org/10.1590/0100-2945-390/13>. Accessed: Sep. 01, 2017. doi: 10.1590/0100-2945-390/13.

KANGA, L.H.B. et. al. Management of insecticide resistance in oriental fruit moth Grapholita molesta (Lepidoptera: Tortricidae) populations from Ontario. Pest Management Science, v.59, n.8, p.921-927, 2003. Available from: <http://dx.doi.org/10.1002/ps.702>. Accessed: Aug. 15, 2017. doi: 10.1002/ps.702.

ROUSH, R.T.; MILLER, G.L. Considerations for design of insecticide resistance monitoring programs. Journal Economic of Entomology, v.79, n.2, p.293-298, 1986. Available from: <https://doi.org/10.1093/ jee/79.2.293 > . Accessed: Aug. 14, 2017. doi: 10.1093/jee/79.2.293.

SAS INSTITUTE. Statistical analysis system: getting started with the SAS learning. SAS Institute, Cary, NC. 2011, 84p.

SIEGWART, M. et al. Tools for resistance monitoring in oriental fruit moth (Lepidoptera: Tortricidae) and first assessment in Brazilian populations. Journal Economic Entomology, v 104, n.2, p.636645, 2011. Available from: <https://doi.org/10.1603/EC10302>. Accessed: Sep. 21, 2017. doi: 10.1603/EC10302.

SILVA-BRANDÃO, K.L. et al. Genotyping-by-sequencing approach indicates geographic distance as the main factor affecting genetic structure and gene flow in Brazilian populations of Grapholita molesta (Lepidoptera:Tortricidae). Evolutionary Applications, v.8, n.5, p.476485, 2015. Available from: <https://doi.org/10.1111/eva.12257>. Accessed: Aug. 20, 2017. doi: 10.1111/eva.12257.

SPARKS T. C; NAUEN. R. IRAC: Mode of action classification and insecticide resistance management. Pesticide Biochemistry and Physiology, v.121, p.122-128, 2015. Available from: $<$ https:// doi.org/10.1016/j.pestbp.2014.11.014>. Accessed: Sep. 20, 2017. doi: 10.1016/j.pestbp.2014.11.014.

USMANI, K. A.; SHEARER. P.W. Susceptibility of male oriental fruit moth (Lepidoptera: Tortricidae) populations from New Jersey apple orchards to azinphosmethyl. Journal Economic of Entomology, v.94, n.4, p.233-239, 2001. Available from: <https:// doi.org/10.1603/0022-0493-94.1.233>. Accessed: May. 20, 2017. doi: 10.1603/0022-0493-94.1.233. 